\title{
Evaluation of Isotopic Abundance Ratio in Biofield Energy Treated Nitrophenol Derivatives Using Gas Chromatography-Mass Spectrometry
}

\author{
Mahendra Kumar Trivedi ${ }^{1}$, Alice Branton ${ }^{1}$, Dahryn Trivedi ${ }^{1}$, Gopal Nayak ${ }^{1}$, Kalyan Kumar Sethi ${ }^{2}$, \\ Snehasis Jana ${ }^{2, *}$ \\ ${ }^{1}$ Trivedi Global Inc., Henderson, USA \\ ${ }^{2}$ Trivedi Science Research Laboratory Pvt. Ltd., Bhopal, Madhya Pradesh, India
}

Email address:

publication@trivedisrl.com (S. Jana)

${ }^{*}$ Corresponding Author

\section{To cite this article:}

Mahendra Kumar Trivedi, Alice Branton, Dahryn Trivedi, Gopal Nayak, Kalyan Kumar Sethi, Snehasis Jana. Evaluation of Isotopic Abundance Ratio in Biofield Energy Treated Nitrophenol Derivatives Using Gas Chromatography-Mass Spectrometry. American Journal of Chemical Engineering. Vol. 4, No. 3, 2016, pp. 68-77. doi: 10.11648/j.ajche.20160403.11

Received: May 10, 2016; Accepted: June 16, 2016; Published: July 15, 2016

\begin{abstract}
Nitrophenols are the synthetic organic chemicals used for the preparation of synthetic intermediates, organophosphorus pesticides, and pharmaceuticals. The objective of the present study was to evaluate the effect of biofield energy treatment on the isotopic abundance ratios of $\mathrm{P}_{\mathrm{M}+1} / \mathrm{P}_{\mathrm{M}}$, and $\mathrm{P}_{\mathrm{M}+2} / \mathrm{P}_{\mathrm{M}}$ in $o$ - and $m$-nitrophenol using the gas chromatography-mass spectrometry. The $o$ - and $m$-nitrophenol were divided into two parts - one part was control sample, and another part was considered as biofield energy treated sample, which received Mr. Trivedi's biofield energy treatment (The Trivedi Effect ${ }^{\circledR}$ ). The biofield energy treated nitrophenols having analyzed at different time intervals were designated as T1, T2, T3, and T4. The GCMS analysis of both the control and biofield treated samples indicated the presence of the parent molecular ion peak of $o$ - and $m$ nitrophenol $\left(\mathrm{C}_{6} \mathrm{H}_{5} \mathrm{NO}_{3}{ }^{+}\right)$at $m / z 139$ along with major fragmentation peaks at $m / z 122,109,93,81,65$, and 39. The relative peak intensities of the fragmented ions in the biofield treated $o$ - and $m$-nitrophenol were notably changed as compared to the control sample with respect to the time. The isotopic abundance ratio analysis using GC-MS revealed that the isotopic abundance ratio of $\mathrm{P}_{\mathrm{M}+1} / \mathrm{P}_{\mathrm{M}}$ in the biofield energy treated $o$-nitrophenol at $\mathrm{T} 2$ and $\mathrm{T} 3$ was significantly increased by 14.48 and $86.49 \%$, respectively as compared to the control sample. Consequently, the isotopic abundance ratio of $\mathrm{P}_{\mathrm{M}+2} / \mathrm{P}_{\mathrm{M}}$ in the biofield energy treated sample at $\mathrm{T} 2$ and T3 was increased by 11.36 , and $82.95 \%$, respectively as compared to the control sample. Similarly, in $m$-nitrophenol, the isotopic abundance ratio of $\mathrm{P}_{\mathrm{M}+1} / \mathrm{P}_{\mathrm{M}}$ in the biofield energy treated sample at T1, T3, and T4 was increased by 5.82, 5.09, and $6.40 \%$, respectively as compared to the control sample. Subsequently, the isotopic abundance ratio of $\mathrm{P}_{\mathrm{M}+2} / \mathrm{P}_{\mathrm{M}}$ at T1, T2, T3 and $\mathrm{T} 4$ in the biofield energy treated $m$-nitrophenol was increased by $6.33,3.80,16.46$, and $16.46 \%$, respectively as compared to the control sample. Overall, the isotopic abundance ratios of $\mathrm{P}_{\mathrm{M}+1} / \mathrm{P}_{\mathrm{M}}\left({ }^{2} \mathrm{H} /{ }^{1} \mathrm{H}\right.$ or ${ }^{13} \mathrm{C} /{ }^{12} \mathrm{C}$ or ${ }^{15} \mathrm{~N} /{ }^{14} \mathrm{~N}$ or $\left.{ }^{17} \mathrm{O} /{ }^{16} \mathrm{O}\right)$, and $\mathrm{P}_{\mathrm{M}+2} / \mathrm{P}_{\mathrm{M}}\left({ }^{18} \mathrm{O} /{ }^{16} \mathrm{O}\right)$ were altered in the biofield energy treated $o$ - and $m$-nitrophenol as compared to the control increased in most of the cases. The biofield treated $o$ - and $m$-nitrophenol that have improved isotopic abundance ratios might have altered the physicochemical properties and could be useful in pharmaceutical and chemical industries as an intermediate in the manufacturing of pharmaceuticals and other useful chemicals for the industrial application.
\end{abstract}

Keywords: Biofield Energy Treatment, the Trivedi Effect ${ }^{\circledR}, o$-Nitrophenol, $m$-Nitrophenol, Isotopic Abundance, Gas Chromatography-Mass Spectrometry

\section{Introduction}

Ortho- and meta-nitrophenol ( $o$ - and $m$-nitrophenol) isomers are water-soluble solids and are manufactured chemicals that do not occur naturally in the environment. The nitrophenol compounds have huge applications and a widely known group of industrial chemicals today. Nitrophenols are 
used as intermediates in the synthesis of some organophosphorus pesticides and pharmaceuticals, i.e. fungicides [1-3]. $o$-Nitrophenol is a light yellow solid with a peculiar sweet smell used in medicine, rubber auxiliaries, dye, reaction intermediate, and indicator of single colour $\mathrm{p}^{\mathrm{H}}$ value $[2,3]$. In spite of many applications $o$ - and $m$ nitrophenol, these compounds have many disadvantages. Releases into the environment are primarily by hydrolytic and photolytic degradation of the respective pesticides and caused by the dry and wet deposition of airborne nitrophenol from the atmosphere [1]. Experiment on mice revealed clinical signs following oral exposure were unspecific and included dyspnoea, staggering, trembling, somnolence, apathy, and cramps [4, 5]. Over the last several years, numerous articles and books have specifically addressed the toxicity and mutagenicity of $o$ - and $m$-nitrophenol [6-9]. Therefore, it is a very important challenge with respect to scientific concern to check the toxicity and hazardous effect of $o$ - and $m$-nitrophenol by means of physicochemical, thermal, and structural modification.

The introduction of heavier stable isotopes to a molecule might be an alternative approach for physicochemical, thermal, and structural modification of $o$ - and $m$-nitrophenol. The stable isotopic ratio analysis widely used in several fields such as geographical, agricultural, food authenticity, biochemistry, metabolism, medical research, and sports, etc. [10-14]. The isotopic abundance of a molecule can be altered by means of chemical reactions [11, 15]. Mr. Trivedi's biofield energy treatment has the remarkable capability to alter the isotopic abundance ratios of various compounds [1620]. For e.g. the isotopic abundance ratio of $\mathrm{P}_{\mathrm{M}+1} / \mathrm{P}_{\mathrm{M}}\left({ }^{13} \mathrm{C} /{ }^{12} \mathrm{C}\right.$ or ${ }^{2} \mathrm{H} /{ }^{1} \mathrm{H}$ or ${ }^{15} \mathrm{~N} /{ }^{14} \mathrm{~N}$ ) in 4-bromoaniline was increased after biofield energy treatment up to $368.3 \%$ [18]. The isotopic abundance ratio of $\mathrm{P}_{\mathrm{M}+2} / \mathrm{P}_{\mathrm{M}}\left({ }^{18} \mathrm{O} /{ }^{16} \mathrm{O}\right.$ or $\left.{ }^{37} \mathrm{Cl} /{ }^{35} \mathrm{Cl}\right)$ in biofield treated 2,4-dichlorophenol was increased by $40.57 \%$, respectively [20]. Biofield energy is an electromagnetic field existed in an around the human body [21-23]. The energy can be harnessed from the universe and then, it can be applied by the healing practitioner on living or non-living objects to achieve the alterations in the characteristic properties. The applications of The Trivedi Effect ${ }^{\circledR}$ have gained significantly scientific attention in the field of materials science [24-31], agriculture [32-34], biotechnology [35-37], pharmaceuticals [38-40], and medical sciences [41, 42].

The choice for the isotope ratio analysis is the mass spectrometry (MS) technique [43]. The gas chromatographymass spectrometry (GC-MS) can perform isotope ratio measurement at low micro molar concentration levels [4346]. Recently, it has been reported that Mr. Trivedi's biofield energy treatment (The Trivedi Effect ${ }^{\mathbb{B}}$ ) has the amazing capability to alter the physicochemical and thermal properties of nitrophenol such as crystallite size, particle size and thermal stability that might affect the rate of chemical reaction [24]. Based on all these aspects, the current study was designed to investigate the isotopic abundance ratios of $\mathrm{P}_{\mathrm{M}+1} / \mathrm{P}_{\mathrm{M}}$ and $\mathrm{P}_{\mathrm{M}+2} / \mathrm{P}_{\mathrm{M}}$ in the biofield energy treated $o$ - and $m$ nitrophenol using the GC-MS technique.

\section{Materials and Method}

\subsection{Chemicals and Reagents}

$o$-Nitrophenol and $m$-nitrophenol were procured from Loba Chemie Pvt. Ltd., India. All the other chemicals used in this experiment were analytical grade purchased from the local vendors.

\subsection{Biofield Energy Treatment Strategies}

$o$-Nitrophenol and $m$-nitrophenol were divided into two parts; one was kept as a control (un-treated) while another part was subjected to biofield energy treatment and coded as treated sample. The treatment groups in sealed pack were handed over to Mr. Trivedi for biofield treatment under standard laboratory condition. Mr. Trivedi provided the biofield energy treatment through his unique energy transmission process approximately for 5 minutes without touching the samples. The biofield treated samples were returned in similar sealed condition for further analysis.

\subsection{Gas Chromatography - Mass Spectrometry (GC-MS)}

GC-MS analysis was conducted on Perkin Elmer/Auto system XL with Turbo mass, USA. The GC-MS was accomplished in a silica capillary column. It was furnished with a quadrupole detector with pre-filter. The mass spectrometer was functioned in an electron ionization (EI) $+\mathrm{ve} /-\mathrm{ve}$, and chemical ionization mode at $70 \mathrm{eV}$. Mass range: 10-650 Daltons (amu), stability: $\pm 0.1 \mathrm{~m} / \mathrm{z}$ mass accuracy over 48 hours. The characterization was performed by the comparison of retention time and the mass spectra of identified substances with references.

\subsection{Methods of GC-MS Analysis and Calculation of Isotopic Abundance Ratio}

The GC-MS analysis of biofield treated $o$-nitrophenol and $m$-nitrophenol were analyzed at the different time intervals designated as $\mathrm{T} 1, \mathrm{~T} 2, \mathrm{~T} 3$, and $\mathrm{T} 4$, respectively. The mass spectra were obtained in the form of $\%$ abundance $v s$. mass to charge ratio $(\mathrm{m} / \mathrm{z})$. The natural abundance of each isotope can be predicted from the comparison of the height of the isotope peak with respect to the base peak. The values of the natural isotopic abundance of the common elements are obtained from several literatures [43-46] and presented in Table 1.

Table 1. The isotopic composition (the natural isotopic abundance) of the elements.

\begin{tabular}{llllll}
\hline Element $(\boldsymbol{A})$ & Symbol & Mass & $\begin{array}{l}\text { \% Natural } \\
\text { Abundance }\end{array}$ & $\begin{array}{l}\boldsymbol{A}+\mathbf{1} \\
\text { Factor }\end{array}$ & $\begin{array}{l}\boldsymbol{A}+\mathbf{2} \\
\text { Factor }\end{array}$ \\
\hline Hydrogen & ${ }^{1} \mathrm{H}$ & 1 & 99.9885 & & \\
& ${ }^{2} \mathrm{H}$ & 2 & 0.0115 & $0.015 \mathrm{n}_{\mathrm{H}}$ & \\
Carbon & ${ }^{12} \mathrm{C}$ & 12 & 98.892 & & \\
& ${ }^{13} \mathrm{C}$ & 13 & 1.108 & $1.1 \mathrm{n}_{\mathrm{C}}$ & \\
& ${ }^{16} \mathrm{O}$ & 16 & 99.762 & & \\
Oxygen & ${ }^{17} \mathrm{O}$ & 17 & 0.038 & $0.04 \mathrm{n}_{\mathrm{O}}$ & \\
& ${ }^{18} \mathrm{O}$ & 18 & 0.200 & & $0.20 \mathrm{n}_{\mathrm{O}}$ \\
Nitrogen & ${ }^{14} \mathrm{~N}$ & 14 & 99.60 & & \\
\hline
\end{tabular}




\begin{tabular}{llllll}
\hline Element $(\boldsymbol{A})$ & Symbol & Mass & $\begin{array}{l}\text { \% Natural } \\
\text { Abundance }\end{array}$ & $\begin{array}{l}\boldsymbol{A}+\mathbf{1} \\
\text { Factor }\end{array}$ & $\begin{array}{l}\boldsymbol{A}+\mathbf{2} \\
\text { Factor }\end{array}$ \\
\hline \multirow{2}{*}{ Chlorine } & ${ }^{35} \mathrm{Cl}$ & 35 & 75.78 & & \\
& ${ }^{37} \mathrm{Cl}$ & 37 & 24.22 & & $32.50 \mathrm{n}_{\mathrm{Cl}}$ \\
\hline
\end{tabular}

$A$ : Element; n: no of $\mathrm{H}, \mathrm{C}, \mathrm{O}, \mathrm{Cl}$, etc.

The following method was used for calculating the isotopic abundance ratio:

$P_{M}$ stands for the relative peak intensity of the parent molecular ion $\left[\mathrm{M}^{+}\right]$expressed in percentage. In other way, it indicates the probability to have $A$ element (for $e . g .{ }^{12} \mathrm{C},{ }^{1} \mathrm{H}$, ${ }^{16} \mathrm{O},{ }^{14} \mathrm{~N}$, etc.) contributions to the mass of the parent molecular ion $\left[\mathrm{M}^{+}\right]$.

$\mathrm{P}_{\mathrm{M}+1}$ represents the relative peak intensity of the isotopic molecular ion $\left[(\mathrm{M}+1)^{+}\right]$expressed in percentage

$=\left(\right.$ no. of $\left.{ }^{13} \mathrm{C} \times 1.1 \%\right)+\left(\right.$ no. of $\left.{ }^{15} \mathrm{~N} \times 0.40 \%\right)+\left(\right.$ no. of ${ }^{2} \mathrm{H} \mathrm{x}$ $0.015 \%)+\left(\right.$ no. of $\left.{ }^{17} \mathrm{O} \times 0.04 \%\right)$

i.e. the probability to have $A+1$ element (for e.g. ${ }^{13} \mathrm{C},{ }^{2} \mathrm{H}$, ${ }^{15} \mathrm{~N}$, etc.) contributions to the mass of the isotopic molecular ion $\left[(\mathrm{M}+1)^{+}\right]$

$\mathrm{P}_{\mathrm{M}+2}$ represents the relative peak intensity of the isotopic molecular ion $\left[(\mathrm{M}+2)^{+}\right]$expressed in the percentage

$=\left(\right.$ no. of $\left.{ }^{18} \mathrm{O} \times 0.20 \%\right)+\left(\right.$ no. of $\left.{ }^{37} \mathrm{Cl} \times 32.50 \%\right)$

i.e. the probability to have $A+2$ element (for e.g. ${ }^{18} \mathrm{O}$, ${ }^{37} \mathrm{Cl},{ }^{34} \mathrm{~S}$, etc.) contributions to the mass of isotopic molecular ion $\left[(\mathrm{M}+2)^{+}\right]$

Isotopic abundance ratio (IAR) for $A+1$ element $=\mathrm{P}_{\mathrm{M}+}$ ${ }_{1} / \mathrm{P}_{\mathrm{M}}$

Similarly, isotopic abundance ratio for $A+2$ element $=$ $\mathrm{P}_{\mathrm{M}+2} / \mathrm{P}_{\mathrm{M}}$

Percentage $(\%)$ change in isotopic abundance ratio $=$ $\left.\left[\left(\mathrm{IAR}_{\text {Treated }}-\mathrm{IAR}_{\text {Control }}\right) / \mathrm{IAR}_{\text {Control }}\right) \times 100\right]$

Where, $\mathrm{IAR}_{\text {Treated }}=$ isotopic abundance ratio in the treated sample and $\mathrm{IAR}_{\mathrm{Control}}=$ isotopic abundance ratio in the control sample.

\section{Results and Discussion}

The mass spectra obtained by the GC-MS analysis for the control and biofield energy treated $o$ - and $m$-nitrophenol $\left(\mathrm{C}_{6} \mathrm{H}_{5} \mathrm{NO}_{3}\right)$ in the positive-ion mode are shown in Figure 1-4. Figure 1 indicated the presence of the parent molecular ion peak of control $o$-nitrophenol at $\mathrm{m} / \mathrm{z} 139$ (calculated 139.03 for $\left.\mathrm{C}_{6} \mathrm{H}_{5} \mathrm{NO}_{3}{ }^{+}\right)$at the retention time $\left(\mathrm{R}_{\mathrm{t}}\right)$ of $9.87 \mathrm{~min}$ along with six major fragmented peaks that were well matched with the literature [47, 48]. The major fragmentation peaks at $\mathrm{m} / \mathrm{z}$ $122,109,93,81,65$, and 39 were due to the fragmentation of $o$-nitrophenol into $\mathrm{C}_{6} \mathrm{H}_{4} \mathrm{NO}_{2}{ }^{+}, \mathrm{C}_{6} \mathrm{H}_{5} \mathrm{O}_{2}{ }^{+}, \mathrm{C}_{6} \mathrm{H}_{5} \mathrm{O}^{+}, \mathrm{C}_{6} \mathrm{H}_{9}^{+}$, $\mathrm{C}_{5} \mathrm{H}_{5}{ }^{+}$, and $\mathrm{C}_{3} \mathrm{H}_{3}{ }^{+{ }^{+}}$, respectively. The biofield energy treated $o$-nitrophenol at $\mathrm{T} 1, \mathrm{~T} 2, \mathrm{~T} 3$, and $\mathrm{T} 4$ exhibited the parent molecular ion peaks $\left(\mathrm{C}_{6} \mathrm{H}_{5} \mathrm{NO}_{3}{ }^{+}\right)$at $m / z 139$ at $\mathrm{R}_{\mathrm{t}}$ of 9.80 , 9.82, 9.84, and $9.86 \mathrm{~min}$ and were very close to the $\mathrm{R}_{\mathrm{t}}$ of the control sample. Similarly, Figure 3 indicated the presence of the parent molecular ion peak of control $o$-nitrophenol at $\mathrm{m} / \mathrm{z}$ 139 (calculated 139.03 for $\mathrm{C}_{6} \mathrm{H}_{5} \mathrm{NO}_{3}{ }^{+}$) at the retention time $\left(R_{t}\right)$ of 15.27 min along with four major fragmented peaks that were well matched with the literature $[48,49]$. The major fragmentation peaks at $m / z 93,81,65$ and 39 were due to the fragmentation of $m$-nitrophenol into $\mathrm{C}_{6} \mathrm{H}_{5} \mathrm{O}^{+}, \mathrm{C}_{6} \mathrm{H}_{9}{ }^{+}, \mathrm{C}_{5} \mathrm{H}_{5}^{+}$, and $\mathrm{C}_{3} \mathrm{H}_{3}{ }^{.+}$, respectively. The biofield energy treated $\mathrm{m}$ nitrophenol at $\mathrm{T} 1, \mathrm{~T} 2, \mathrm{~T} 3$, and $\mathrm{T} 4$ shown the parent molecular ion peaks $\left(\mathrm{C}_{6} \mathrm{H}_{5} \mathrm{NO}_{3}{ }^{+}\right)$at $m / z 139$ at $\mathrm{R}_{\mathrm{t}}$ of 15.19 , $15.19,15.21$, and $15.29 \mathrm{~min}$ and were very close to the $\mathrm{R}_{t}$ of the control sample. The biofield energy treated $o$ - and $m$ nitrophenol at T1, T2, T3, and T4 showed similar fragmentation pattern as control (Figure 2 and 4). Only, the relative peak intensities of both the biofield treated samples were altered as compared to the control samples (Figure 1-4).

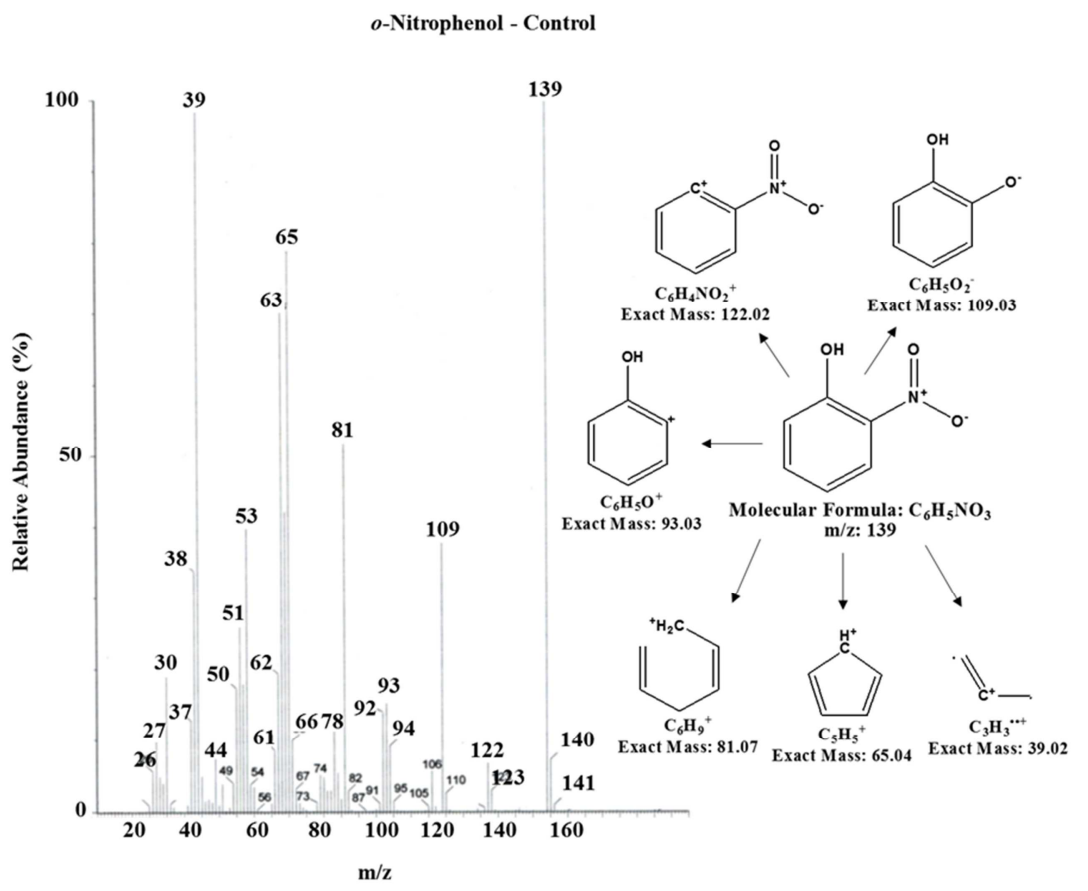

Figure 1. The GC-MS spectrum and different possible fragmentation of control sample of o-nitrophenol. 
Mahendra Kumar Trivedi et al:: Evaluation of Isotopic Abundance Ratio in Biofield Energy Treated Nitrophenol Derivatives Using Gas Chromatography-Mass Spectrometry
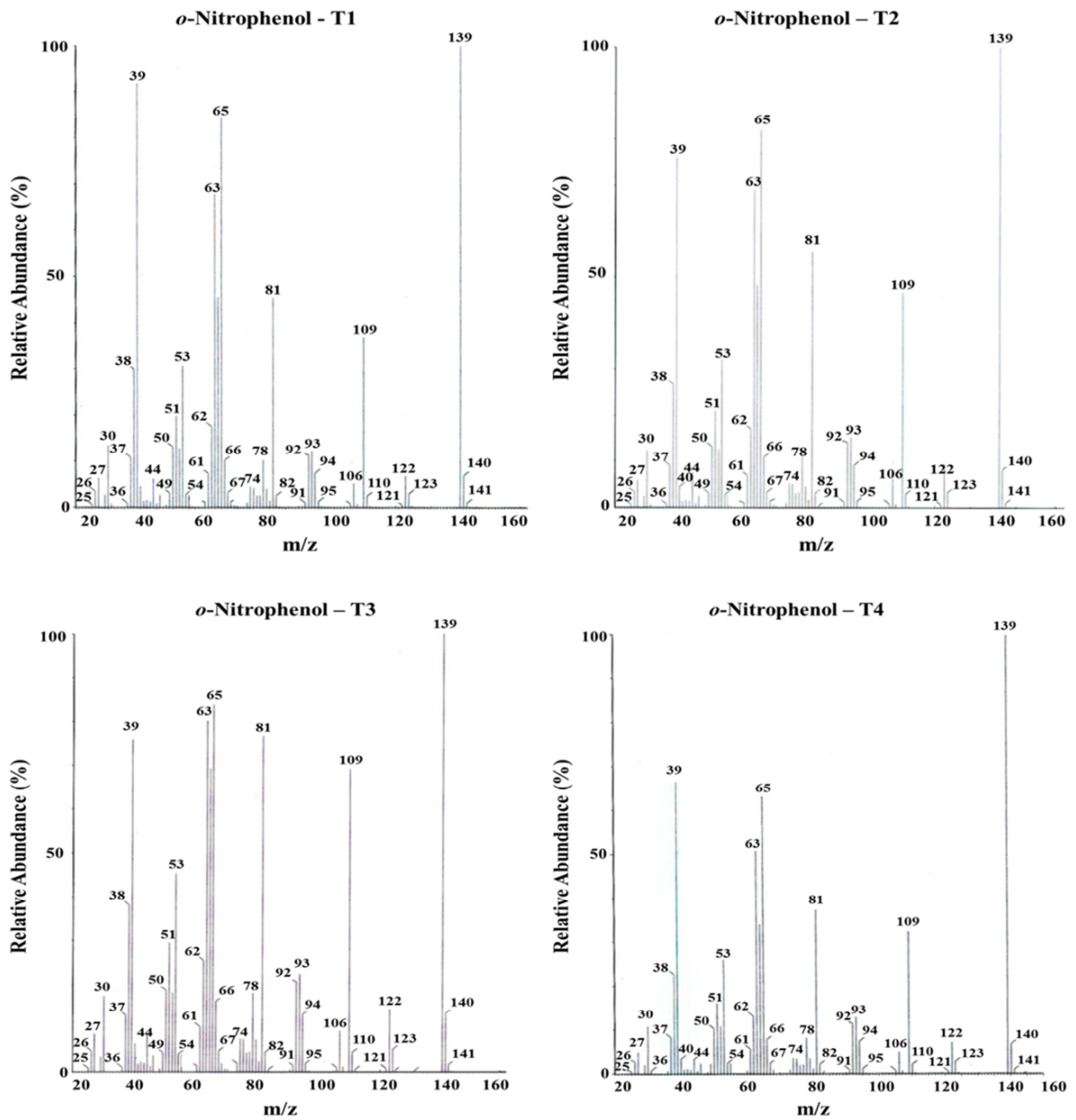

Figure 2. The GC-MS spectrum of biofield energy treated o-nitrophenol analyzed at the different time intervals T1, T2, T3, and T4.

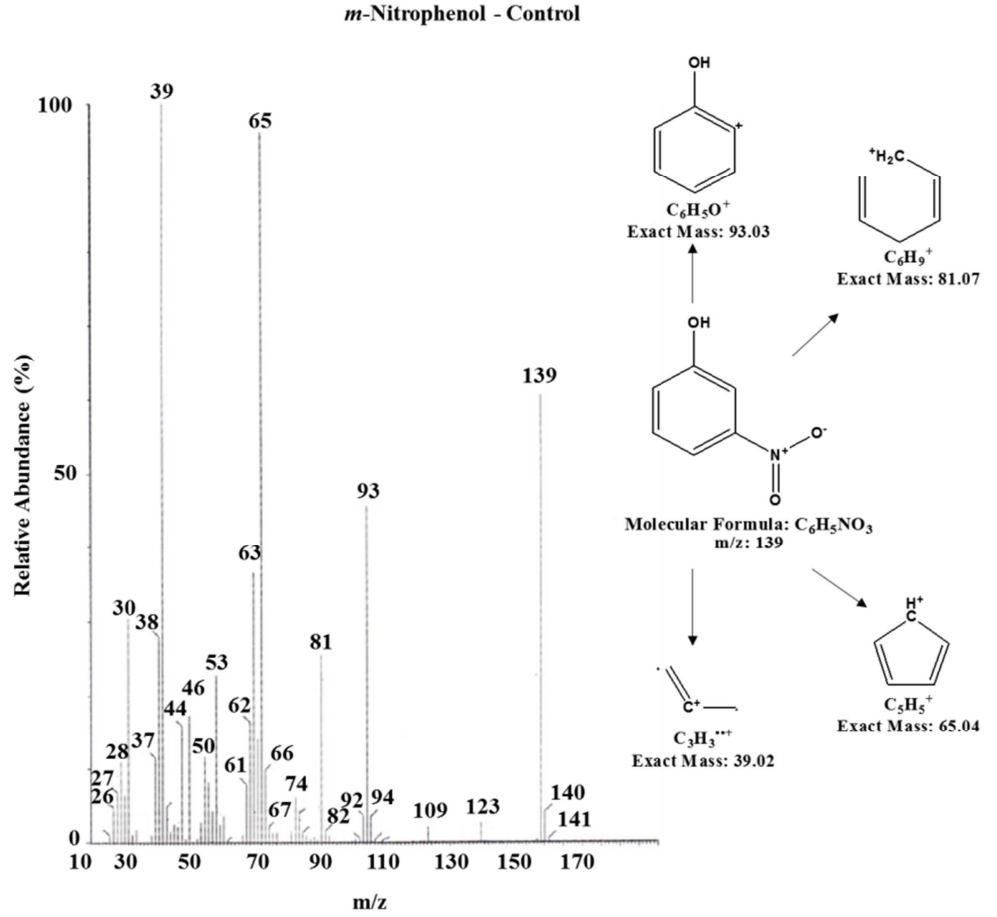

Figure 3. The GC-MS spectrum and different possible fragmentation of the control sample of m-notrophenol. 


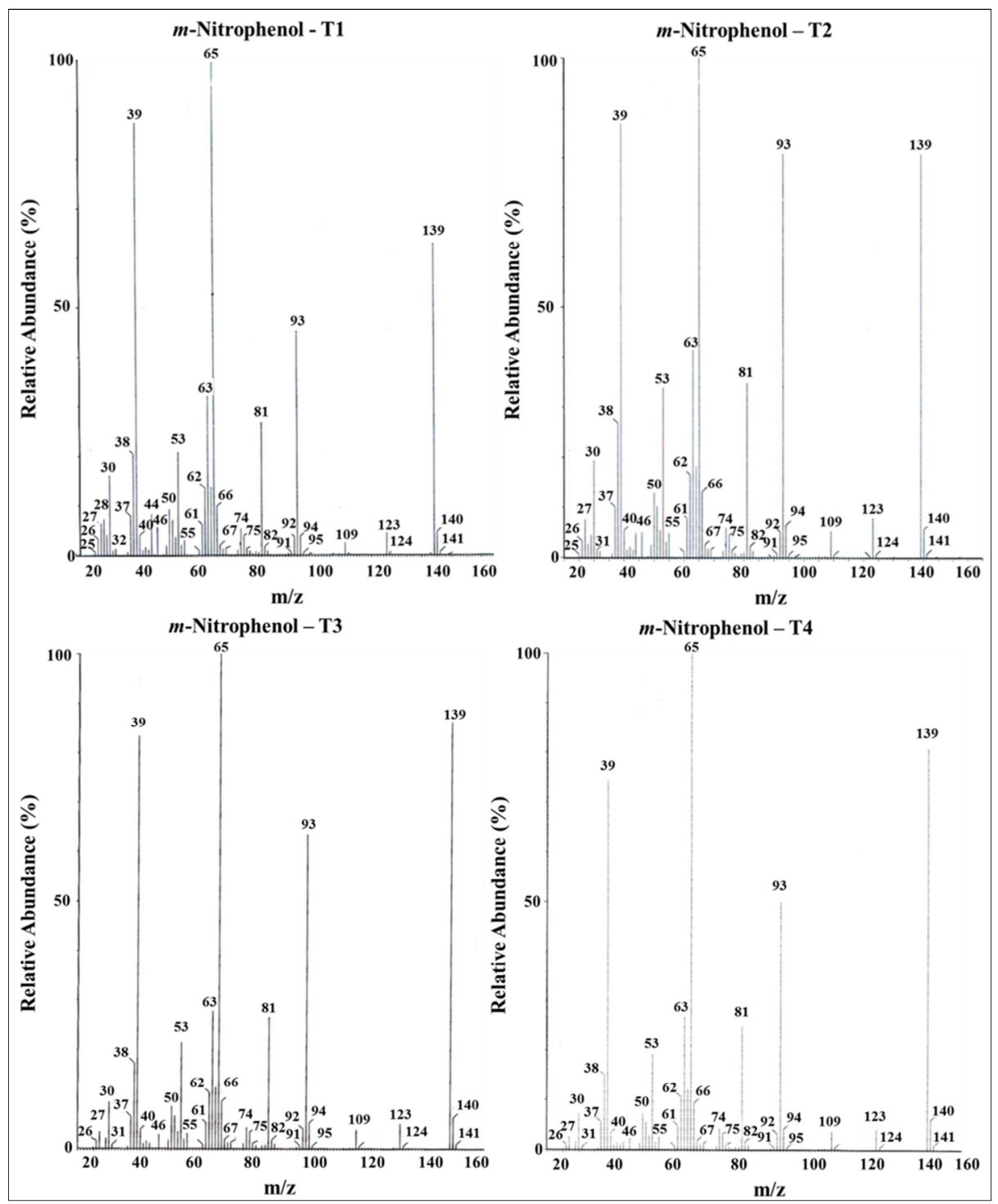

Figure 4. The GC-MS spectrum of biofield energy treated m-nitrophenol analyzed at the different time intervals T1, T2, T3, and T4.

The molecule $o$ - and $m$-nitrophenol $\left(\mathrm{C}_{6} \mathrm{H}_{5} \mathrm{NO}_{3}\right)$ comprises several atoms of $\mathrm{H}, \mathrm{C}, \mathrm{N}$, and $\mathrm{O}$. Calculating the relative abundances for the isotopic contributions to the peaks in various ion clusters at low $\mathrm{m} / \mathrm{z}$ discrimination will reflect the contributions of several different isotopes to the same peak $[45,46,50,51]$. The intense peak $\mathrm{P}_{\mathrm{M}}$ in this cluster was at $\mathrm{m} / \mathrm{z} 139$, and all the abundance calculations were based on this. $\mathrm{P}_{\mathrm{M}+1}$ and $\mathrm{P}_{\mathrm{M}+2}$ of $o$-nitrophenol can be calculated theoretically according to the method described in the materials and method.

$\mathrm{P}\left({ }^{13} \mathrm{C}\right)=\left[(6 \times 1.1 \%) \times 100 \%\right.$ (the actual size of the $\mathrm{M}^{+}$ peak) $] / 100 \%=6.6 \%$

$\mathrm{P}\left({ }^{2} \mathrm{H}\right)=[(5 \times 0.015 \%) \times 100 \%] / 100 \%=0.075 \%$

$\mathrm{P}\left({ }^{15} \mathrm{~N}\right)=[(1 \times 0.40 \%) \times 100 \%] / 100 \%=0.4 \%$

$\mathrm{P}\left({ }^{17} \mathrm{O}\right)=[(3 \times 0.04 \%) \times 100 \%] / 100 \%=0.12 \%$

Thus, $\mathrm{P}_{\mathrm{M}+1}$ i.e. ${ }^{13} \mathrm{C},{ }^{2} \mathrm{H},{ }^{15} \mathrm{~N}$, and ${ }^{17} \mathrm{O}$ contributions from $\left(\mathrm{C}_{6} \mathrm{H}_{5} \mathrm{NO}_{3}{ }^{+}\right)$to $\mathrm{m} / \mathrm{z} 140$ is $7.195 \%$

$\mathrm{P}\left({ }^{18} \mathrm{O}\right)=[(3 \times 0.2 \%) \times 100 \%] / 100 \%=0.6 \%$

So, $\mathrm{P}_{\mathrm{M}+2}$ i.e. ${ }^{18} \mathrm{O}$ contributions from $\left(\mathrm{C}_{6} \mathrm{H}_{5} \mathrm{NO}_{3}{ }^{+}\right)$to $\mathrm{m} / z 141$ is $0.6 \%$
Similarly, the $\mathrm{P}_{\mathrm{M}+1}$ and $\mathrm{P}_{\mathrm{M}+2}$ of $m$-nitrophenol can be calculated theoretically according to the method described in the materials and method.

$\mathrm{P}\left({ }^{13} \mathrm{C}\right)=\left[(6 \times 1.1 \%) \times 60.56 \%\right.$ (the actual size of the $\mathrm{M}^{+}$ peak) $] / 100 \%=3.99 \%$

$$
\begin{aligned}
& \mathrm{P}\left({ }^{2} \mathrm{H}\right)=[(5 \times 0.015 \%) \times 60.56 \%] / 100 \%=0.045 \% \\
& \mathrm{P}\left({ }^{15} \mathrm{~N}\right)=[(1 \times 0.40 \%) \times 60.56 \%] / 100 \%=0.24 \% \\
& \mathrm{P}\left({ }^{17} \mathrm{O}\right)=[(3 \times 0.04 \%) \times 60.56 \%] / 100 \%=0.072 \%
\end{aligned}
$$

Thus, $\mathrm{P}_{\mathrm{M}+1}$ i.e. ${ }^{13} \mathrm{C},{ }^{2} \mathrm{H},{ }^{15} \mathrm{~N}$, and ${ }^{17} \mathrm{O}$ contributions from $\left(\mathrm{C}_{6} \mathrm{H}_{5} \mathrm{NO}_{3}{ }^{+}\right)$to $\mathrm{m} / \mathrm{z} 140$ is $4.35 \%$

$\mathrm{P}\left({ }^{18} \mathrm{O}\right)=[(3 \times 0.2 \%) \times 60.56 \%] / 100 \%=0.36 \%$

So, $\mathrm{P}_{\mathrm{M}+2}$ i.e. ${ }^{18} \mathrm{O}$ contributions from $\left(\mathrm{C}_{6} \mathrm{H}_{5} \mathrm{NO}_{3}{ }^{+}\right)$to $\mathrm{m} / z 141$ is $0.36 \%$

The calculated abundance of $\mathrm{P}_{\mathrm{M}+1}$ and $\mathrm{P}_{\mathrm{M}+2}$ in $o$ - and $m$ nitrophenol matched to the experimental value obtained in the control sample. It has been found that statistically, the coincidental of both carbons being ${ }^{13} \mathrm{C}$ is approximately 1 in $10,000[43,44]$. The deuterium did not contribute much any of the $\mathrm{m} / \mathrm{z}$ ratios in natural $o$ - and $m$-nitrophenol as the natural abundance of deuterium is too small relative to the 
natural abundances of isotopes of carbon nitrogen and oxygen [52-55]. From the calculations, ${ }^{13} \mathrm{C},{ }^{15} \mathrm{~N},{ }^{17} \mathrm{O}$, and ${ }^{18} \mathrm{O}$ have the major contributions from $o$ - and $m$-nitrophenol to $m / z 140$ and 141 .

$\mathrm{P}_{\mathrm{M}}, \mathrm{P}_{\mathrm{M}+1}$, and $\mathrm{P}_{\mathrm{M}+2}$ for the control and biofield energy treated nitrophenol at $\mathrm{m} / \mathrm{z} 139,140$, and 141, respectively were achieved from the observed relative intensity of $\left[\mathrm{M}^{+}\right]$, $\left[(\mathrm{M}+1)^{+}\right]$, and $\left[(\mathrm{M}+2)^{+}\right]$peaks in the GC-MS spectra, respectively and are shown in the Table 2 and 3. The percentage change in isotopic abundance ratios of $\mathrm{P}_{\mathrm{M}+1} / \mathrm{P}_{\mathrm{M}}$, and $\mathrm{P}_{\mathrm{M}+2} / \mathrm{P}_{\mathrm{M}}$ in the biofield treated $o$ - and $m$-nitrophenol are presented in Table 2 and 3 , respectively. The isotopic abundance ratios in the biofield energy treated $o$ - and $m$ nitrophenol (at T1 to T4) were calculated comparing to the control sample using the mass spectrum (Table 2 and 3 ).

Table 2. GC-MS isotopic abundance analysis result of control and biofield energy treated o-nitrophenol.

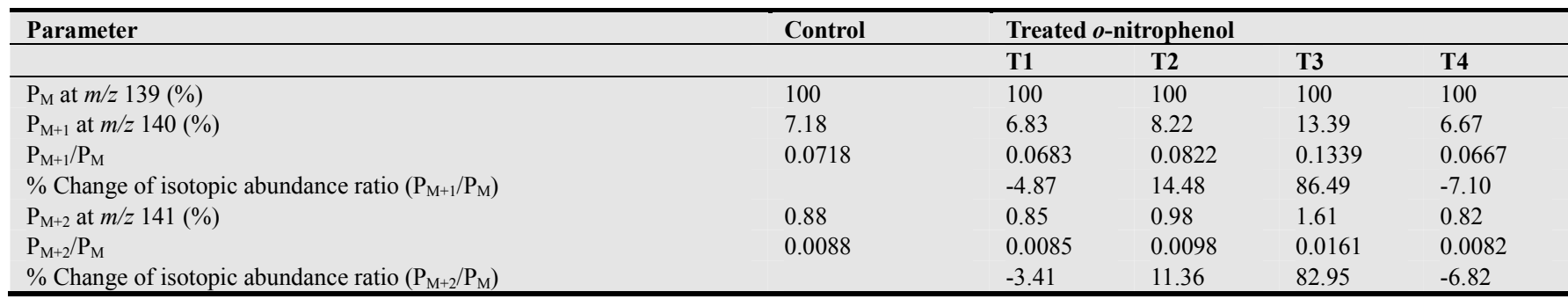

T1, T2, T3, and T4: biofield energy treated sample analyzed at different time intervals; $\mathrm{P}_{\mathrm{M}}$ : the relative peak intensity of the parent molecular ion [M $\mathrm{M}^{+}$; $\mathrm{P}_{\mathrm{M}+1}$ : the relative peak intensity of the isotopic molecular ion $\left[(\mathrm{M}+1)^{+}\right] ; \mathrm{P}_{\mathrm{M}+2}$ : the relative peak intensity of the isotopic molecular ion $\left[(\mathrm{M}+2)^{+}\right]$.

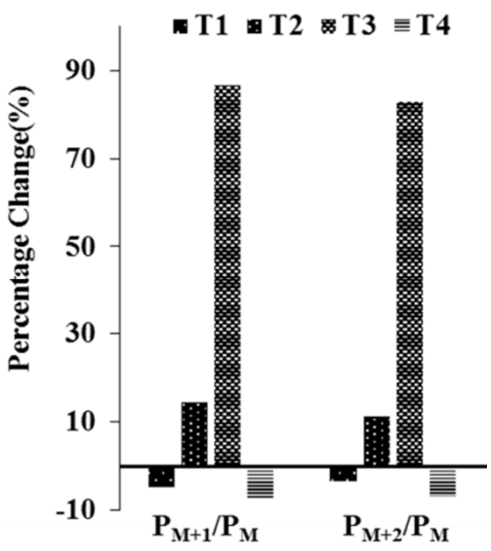

Figure 5. Percent change in the isotopic abundance ratio of $P_{M+1} / P_{M}$ and $P_{M+2} / P_{M}$ in the biofield treated o-nitrophenol as compared to the control.

The isotopic abundance ratios in $o$-nitrophenol using GCMS analysis revealed that the isotopic abundance ratio of $\mathrm{P}_{\mathrm{M}+1} / \mathrm{P}_{\mathrm{M}}$ in the biofield energy treated sample at $\mathrm{T} 2$ and $\mathrm{T} 3$ was significantly increased by 14.48 and $86.49 \%$, respectively in comparison to the control sample (Table 2 and Figure 5). On the contrary, the isotopic abundance ratio of $\mathrm{P}_{\mathrm{M}+1} / \mathrm{P}_{\mathrm{M}}$ in the biofield energy treated $o$-nitrophenol at $\mathrm{T} 1$ and T4 was slightly decreased by 4.87 and $7.10 \%$, respectively as compared to the control sample (Table 2 and Figure 5). Consequently, the isotopic abundance ratio of $\mathrm{P}_{\mathrm{M}+2} / \mathrm{P}_{\mathrm{M}}$ in the biofield energy treated $o$-nitrophenol at $\mathrm{T} 2$ and T3 was increased by 11.36 and $82.95 \%$, respectively as compared to the control sample. But, the isotopic abundance ratio of $\mathrm{P}_{\mathrm{M}+2} / \mathrm{P}_{\mathrm{M}}$ in the biofield energy treated sample at $\mathrm{T} 1$ and T4 were decreased by 3.41 and 6.82 , respectively in comparison to the control $o$-nitrophenol (Table 2 and Figure 5). Similarly, the isotopic abundance ratios of $m$-nitrophenol using GC-MS analysis revealed that the isotopic abundance ratio of $\mathrm{P}_{\mathrm{M}+1} / \mathrm{P}_{\mathrm{M}}$ in the biofield energy treated sample at $\mathrm{T} 1$, $\mathrm{T} 3$, and T4 was increased by 5.82, 5.09, and 6.40\%, respectively in comparison to the control sample (Table 3 and Figure 6). On the other hand, the isotopic abundance ratio of $\mathrm{P}_{\mathrm{M}+1} / \mathrm{P}_{\mathrm{M}}$ in biofield energy treated $m$-nitrophenol at T2 was slightly decreased by $0.29 \%$ in comparison to the control sample (Table 3 and Figure 6). Subsequently, the isotopic abundance ratio of $\mathrm{P}_{\mathrm{M}+2} / \mathrm{P}_{\mathrm{M}}$ in biofield energy treated $m$ nitrophenol at $\mathrm{T} 1, \mathrm{~T} 2, \mathrm{~T} 3$ and $\mathrm{T} 4$ was increased by 6.33 , $3.80,16.46$, and $16.46 \%$, respectively in comparison to the control sample (Table 3 and Figure 5).

Table 3. GC-MS isotopic abundance ratios analysis results of control and biofield energy treated m-nitrophenol.

\begin{tabular}{llllll}
\hline Parameter & Control & \multicolumn{3}{l}{ Treated $\boldsymbol{m}$-nitrophenol } \\
\hline & & T1 & T2 & T3 & T4 \\
\hline $\mathrm{P}_{\mathrm{M}}$ at $m / z 139(\%)$ & 60.56 & 62.88 & 80.56 & 86.19 & 81.26 \\
$\mathrm{P}_{\mathrm{M}+1}$ at $m / z 140(\%)$ & 4.16 & 4.57 & 5.52 & 6.22 & 5.94 \\
$\mathrm{P}_{\mathrm{M}+1} / \mathrm{P}_{\mathrm{M}}$ & 0.0687 & 0.0727 & 0.0685 & 0.0722 & 0.0731 \\
\% Change of isotopic abundance ratio $\left(\mathrm{P}_{\mathrm{M}+1} / \mathrm{P}_{\mathrm{M}}\right)$ & & 5.82 & -0.29 & 5.09 & 6.40 \\
$\mathrm{P}_{\mathrm{M}+2}$ at $m / z$ 141 (\%) & 0.48 & 0.53 & 0.66 & 0.79 & 0.75 \\
$\mathrm{P}_{\mathrm{M}+2} / \mathrm{P}_{\mathrm{M}}$ & 0.0079 & 0.0084 & 0.0082 & 0.0092 & 0.0092 \\
\% Change of isotopic abundance ratio $\left(\mathrm{P}_{\mathrm{M}+2} / \mathrm{P}_{\mathrm{M}}\right)$ & & 6.33 & 3.80 & 16.46 & 16.46 \\
\hline
\end{tabular}

T1, T2, T3, and T4: biofield energy treated sample analyzed at different time intervals; $\mathrm{P}_{\mathrm{M}}$ : the relative peak intensity of the parent molecular ion [M $\left.\mathrm{M}^{+}\right] ; \mathrm{P}_{\mathrm{M}+1}$ : the relative peak intensity of the isotopic molecular ion $\left[(\mathrm{M}+1)^{+}\right] ; \mathrm{P}_{\mathrm{M}+2}$ : the relative peak intensity of the isotopic molecular ion $\left[(\mathrm{M}+2)^{+}\right]$. 


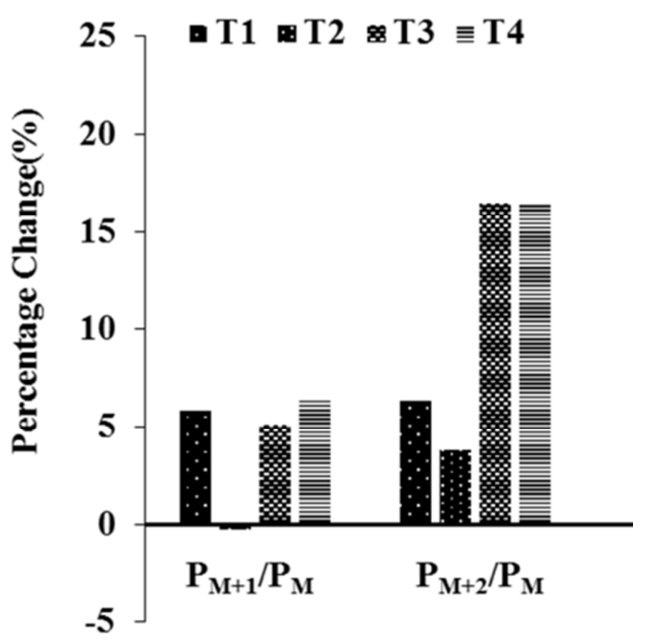

Figure 6. Percent change in the isotopic abundance of $P_{M+1} / P_{M}$ and $P_{M+2} / P_{M}$ in the biofield treated m-nitrophenol as compared to the control.

The Figure 4 and 5 clearly suggest that there was a different effect of the isotopic abundance ratios $\left(\mathrm{P}_{\mathrm{M}+1} / \mathrm{P}_{\mathrm{M}}\right.$ and $\mathrm{P}_{\mathrm{M}+2}$ ) in the biofield energy treated $o$ - and $m$-nitrophenol with respect to the time. This results indicated that these biofield treated samples had the time dependent response to the alternation of isotopic abundance composition. These results propose that the biofield energy might have required a certain time for the changes in the isotopic abundance ratio of the molecule.

Alteration of the isotopic composition of the molecule alters the vibrational energy $[56,57]$. The vibrational energy depends on the reduced mass $(\mu)$ for a diatomic molecule as shown in the below:

$$
E_{0}=\frac{h}{4 \pi} \sqrt{\frac{f}{\mu}} \text { and reduced mass }(\mu)=\frac{m_{a} m_{b}}{m_{a}+m_{b}}
$$

Where, $E_{0}=$ the vibrational energy of a harmonic oscillator at absolute zero or zero point energy; $f=$ force constant.

The reduced mass $(\mu)$ of some probable isotopic bonds was calculated and presented in Table 4 . The results showed that reduced mass were increased in the case of heavier isotopes as compared to normal bond (Table 4). As per the literature, the heavier isotopic molecules have lower diffusion velocity, mobility, evaporation rate, thermal decomposition and reaction rate, but having higher binding energy than lighter molecules [56-59]. The biofield energy treated $o$ - and $m$-nitrophenol have the higher isotopic abundance ratios. Therefore, after biofield energy treatment, the bond strength, stability, and binding energy of $o$ - and $m$ nitrophenol molecules might be increase due to the higher reduced mass.

Table 4. Possible isotopic bonds in o- and m-nitrophenol.

\begin{tabular}{llll}
\hline Isotopes bond & Isotope type & Reduced mass $(\boldsymbol{\mu})\left(\mathbf{m}_{\mathbf{A}} \cdot \mathbf{m}_{\mathbf{B}}\right) /\left(\mathbf{m}_{\mathbf{A}}+\mathbf{m}_{\mathbf{B}}\right)$ & Zero point vibrational energy $\left(\boldsymbol{E}_{\boldsymbol{0}}\right)$ \\
\hline${ }^{12} \mathrm{C}-{ }^{12} \mathrm{C}$ & Lighter & 6.00 & Higher \\
${ }^{13} \mathrm{C}-{ }^{12} \mathrm{C}$ & Heavier & 6.24 & Smaller \\
${ }^{1} \mathrm{H}-{ }^{-12} \mathrm{C}$ & Lighter & 0.92 & Higher \\
${ }^{2} \mathrm{H}^{-12} \mathrm{C}$ & Heavier & 1.71 & Smaller \\
${ }^{16} \mathrm{O}-{ }^{-} \mathrm{H}$ & Lighter & 0.94 & Higher \\
${ }^{16} \mathrm{O}-{ }^{-2} \mathrm{H}$ & Heavier & 1.78 & Smaller \\
${ }^{17} \mathrm{O}-{ }^{-2} \mathrm{H}$ & Heavier & 1.79 & Smaller \\
${ }^{18} \mathrm{O}-{ }^{-} \mathrm{H}$ & Heavier & 1.80 & Smaller \\
${ }^{16} \mathrm{O}-{ }^{12} \mathrm{C}$ & Lighter & 6.86 & Higher \\
${ }^{16} \mathrm{O}-{ }^{13} \mathrm{C}$ & Heavier & 7.17 & Smaller \\
${ }^{17} \mathrm{O}-{ }^{12} \mathrm{C}$ & Heavier & 7.03 & Smaller \\
${ }^{18} \mathrm{O}-{ }^{12} \mathrm{C}$ & Heavier & 7.20 & Smaller \\
${ }^{14} \mathrm{~N}-{ }^{16} \mathrm{O}$ & Lighter & 7.47 & Higher \\
${ }^{15} \mathrm{~N}-{ }^{18} \mathrm{O}$ & Heavier & 8.18 & Smaller \\
${ }^{14} \mathrm{~N}-{ }^{18} \mathrm{O}$ & Heavier & 7.87 & Smaller \\
${ }^{14} \mathrm{~N}-{ }^{12} \mathrm{C}$ & Lighter & 6.46 & Higher \\
${ }^{15} \mathrm{~N}-{ }^{12} \mathrm{C}$ & Heavier & 6.67 & Smaller \\
${ }^{15} \mathrm{~N}-{ }^{13} \mathrm{C}$ & Heavier & 6.96 & Smaller \\
\hline
\end{tabular}

$\mathrm{m}_{\mathrm{A}}$ : mass of atom $\mathrm{A} ; \mathrm{m}_{\mathrm{B}}$ : mass of atom $\mathrm{B}$, here $\mathrm{A}$ and $\mathrm{B}$ may be $\mathrm{C}$ or $\mathrm{H}$ or $\mathrm{N}$ or $\mathrm{O}$.

The isotopic abundance ratios of $\mathrm{P}_{\mathrm{M}+1} / \mathrm{P}_{\mathrm{M}}\left({ }^{2} \mathrm{H} /{ }^{1} \mathrm{H}\right.$ or ${ }^{13} \mathrm{C} /{ }^{12} \mathrm{C}$ or ${ }^{15} \mathrm{~N} /{ }^{14} \mathrm{~N}$ or $\left.{ }^{17} \mathrm{O} /{ }^{16} \mathrm{O}\right)$, and $\mathrm{P}_{\mathrm{M}+2} / \mathrm{P}_{\mathrm{M}}\left({ }^{18} \mathrm{O} /{ }^{16} \mathrm{O}\right)$ in the biofield treated $o$ - and $m$-nitrophenol were significantly increased in most of the cases as compared to the control sample. The recent physics Noble prize winners explained that the neutrinos change, identities which are only possible if the neutrinos possess mass and have the ability to interchange their phase internally from one phase to another (change of flavour). So, the neutrinos have the ability to interact with protons and neutrons in the nucleus. This indicated that there was a close relation between neutrino and the isotope formation [60, 61].
The biofield energy treatment responsible for the modification in the behaviour at atomic and molecular level by changing the neutron to proton ratio in the nucleus possibly through the introduction of neutrino particles. It was hypothesized that due to changes in nuclei possibly through the interference of neutrinos the changes in isotopic abundance. As the biofield treated $o$ - and $m$-nitrophenol had increased the stable isotopic abundance ratio, it might have altered physicochemical and thermal properties and reaction rate. Thus, the current findings are well associated with the previous results [24]. The biofield treated $o$ - and $m$-nitrophenol might be useful in pharmaceutical 
and chemical industries as an intermediate for the production of pharmaceuticals and other useful chemicals for the industrial uses.

\section{Conclusions}

The current study concluded that the biofield energy treatment has a remarkable ability for altering the isotopic abundance ratios in $o$ - and $m$-nitrophenol. The gas chromatography-mass spectrometric (GC-MS) analysis of the both control and biofield energy treated samples indicated the presence of the molecular ion peak at $\mathrm{m} / \mathrm{z} 139$ (calculated 139.03 for $\mathrm{C}_{6} \mathrm{H}_{5} \mathrm{NO}_{3}{ }^{+}$) along with major fragmented peaks at $m / z 122,109,93,81,65$, and 39. Only, the relative peak intensities of the fragmented ions in the biofield treated samples were altered from the control samples. The isotopic abundance ratio of biofield energy treated $o$-nitrophenol exhibited that the isotopic abundance ratio of $\mathrm{P}_{\mathrm{M}+1} / \mathrm{P}_{\mathrm{M}}$ at the $\mathrm{T} 2$ and T3 was significantly increased by 14.48 and $86.49 \%$, respectively as compared to the control sample. Subsequently, the isotopic abundance ratio of $\mathrm{P}_{\mathrm{M}+2} / \mathrm{P}_{\mathrm{M}}$ in biofield energy treated $o$-nitrophenol at T2 and T3 was increased by 11.36 and $82.95 \%$, respectively as compared to the control sample. Similarly, the isotopic abundance ratio of biofield treated $m$-nitrophenol revealed the isotopic abundance ratio of $\mathrm{P}_{\mathrm{M}+1} / \mathrm{P}_{\mathrm{M}}$ at $\mathrm{T} 1, \mathrm{~T} 3$, and $\mathrm{T} 4$ was increased by $5.82,5.09$, and $6.40 \%$, respectively as compared to the control sample. The isotopic abundance ratio of $\mathrm{P}_{\mathrm{M}+2} / \mathrm{P}_{\mathrm{M}}$ in the biofield energy treated $m$-nitrophenol at T1, T2, T3 and T4 was increased by $6.33,3.80,16.46$, and $16.46 \%$, respectively in comparison to the control sample. It was observed that the isotopic abundance ratios of $\mathrm{P}_{\mathrm{M}+1} / \mathrm{P}_{\mathrm{M}}$ and $\mathrm{P}_{\mathrm{M}+2} / \mathrm{P}_{\mathrm{M}}$ in the biofield treated samples were altered with respect to the time. The biofield energy treated $o$ - and $m$ nitrophenol had increased isotopic abundance ratio, it might have altered the physicochemical, thermal properties, and could be more advantageous in pharmaceutical and chemical industries as intermediates during the preparation of the fine finished product.

\section{Abbreviations}

A: Element; GC-MS: Gas chromatography-mass spectrometry; $m / z$ : Mass-to-charge ratio; M: Mass of the parent molecule; $\mathrm{P}_{\mathrm{M}}$ : the relative peak intensity of the parent molecular ion $\left[\mathrm{M}^{+}\right] ; \mathrm{P}_{\mathrm{M}+1}$ : the relative peak intensity of the isotopic molecular ion $\left[(\mathrm{M}+1)^{+}\right] ; \mathrm{P}_{\mathrm{M}+2}$ : the relative peak intensity of the isotopic molecular ion $\left[(\mathrm{M}+2)^{+}\right]$.

\section{Acknowledgements}

The authors would like to thank the Sophisticated Instrumentation Centre for Applied Research and Testing (SICART), Gujarat, India for providing the instrumental facility. The authors are very grateful for the support from Trivedi Science, Trivedi Master Wellness and Trivedi Testimonials in this research work.

\section{References}

[1] Boehncke A, Koennecker G, Mangelsdorf I, Wibbertmann A (2000) Concise international chemical assessment document 20, Mononitrophenols. World Health Organization, Geneva.

[2] https://pubchem.ncbi.nlm.nih.gov/compound/2-nitrophenol.

[3] Ju KS, Parales RE (2010) Nitroaromatic compounds, from synthesis to biodegradation. Microbiol Mol Biol Rev 74: 250272 .

[4] Vernot EH, MacEwen JD, Haun CC, Kinkead ER (1977) Acute toxicity and skin corrosion data for some organic and inorganic compounds and aqueous solutions. Toxicol Appl Pharmacol 42: 417-423

[5] Vasilenko NM, Volodchenko VA, Baturina TS, Kolodub FA (1976) Toxicological peculiarities of mononitrophenols with regard for their isomeric form. Farmakol Toksikol (Moscow) 39: 718-721.

[6] Sunahara GI, Lotufo G, Kuperman RG, Hawari J (2009) Ecotoxicology of explosives. CRC Press, Boca Raton, FL.

[7] Padda RSC, Wang JB, Kutty HR, Bennett GN (2003) Mutagenicity of nitroaromatic degradation compounds. Environ Toxicol Chem 22: 2293-2297.

[8] https://pubchem.ncbi.nlm.nih.gov/compound/2nitrophenol\#datasheet $=\mathrm{lcss} \&$ section $=$ Top.

[9] http://www.clayton.edu/portals/690/chemistry/inventory/MSD S\%203\%20nitrophenol.pdf

[10] Winderl C, Penning H, von Netzer F, Meckenstock RU, Lueders T (2010) DNA-SIP identifies sulfate-reducing Clostridia as important toluene degraders in tar-oilcontaminated aquifer sediment. The ISME Journal 4: 13141325 .

[11] Muccio Z, Jackson GP (2009) Isotope ratio mass spectrometry. Analyst 134: 213-222.

[12] Ben-David M, Flaherty EA (2012) Stable isotopes in mammalian research: A beginner's guide. J Mammal 93: 312328.

[13] Scott, KM, Fox, G, Girguis PR (2011) Measuring isotope fractionation by autotrophic microorganisms and enzymes. Methods Enzymol 494: 281-299.

[14] Morgan JLL, Skulan JL, Gordon GW, Romaniello SJ, Smith SM, Anbar AD (2012) Rapidly assessing changes in bone mineral balance using natural stable calcium isotopes. Proc Natl Acad Sci USA 109: 9989-9994.

[15] Robert R, Seal II (2006) Sulfur isotope geochemistry of sulfide minerals. Rev Mineral Geochem 61: 633-677.

[16] Trivedi MK, Branton A, Trivedi D, Nayak G, Saikia G, Jana S (2015) Evaluation of isotopic abundance ratio of naphthalene derivatives after biofield energy treatment using gas chromatography-mass spectrometry. American Journal of Applied Chemistry 3: 194-200.

[17] Trivedi MK, Branton A, Trivedi D, Nayak G, Saikia G, Jana S (2015) Isotopic abundance analysis of biofield treated benzene, toluene and $p$-xylene using gas chromatography-mass spectrometry (GC-MS). Mass Spectrom Open Access 1: 102. 
[18] Trivedi MK, Branton A, Trivedi D, Nayak G, Saikia G, Jana S (2015) Influence of biofield energy treatment on isotopic abundance ratio in aniline derivatives. Mod Chem appl 3: 168.

[19] Trivedi MK, Branton A, Trivedi D, Nayak G, Saikia G, Jana S (2015) Quantitative determination of isotopic abundance ratio of ${ }^{13} \mathrm{C},{ }^{2} \mathrm{H}$, and ${ }^{18} \mathrm{O}$ in biofield energy treated ortho and meta toluic acid isomers. American Journal of Applied Chemistry 3: $217-223$.

[20] Trivedi MK, Branton A, Trivedi D, Nayak G, Saikia G, Jana S (2015) Determination of isotopic abundance of ${ }^{2} \mathrm{H},{ }^{13} \mathrm{C},{ }^{18} \mathrm{O}$, and ${ }^{37} \mathrm{Cl}$ in biofield energy treated dichlorophenol isomers. Science Journal of Analytical Chemistry 4: 1-6.

[21] Hammerschlag R, Jain S, Baldwin AL, Gronowicz G, Lutgendor SK, Oschman JL, Yount GL (2012) Biofield research: A roundtable discussion of scientific and methodological issues. J Altern Complement Med 18: 10811086 .

[22] Warber SL, Cornelio D, Straughn J, Kile G (2004) Biofield energy healing from the inside. J Altern Complement Med 10: 1107-1113.

[23] Rubik B (2002) The biofield hypothesis: Its biophysical basis and role in medicine. J Altern Complement Med 8: 703-717.

[24] Trivedi MK, Tallapragada RM, Branton A, Trivedi D, Nayak G, et al. (2015) Biofield treatment: an effective strategy for modulating the physical and thermal properties of $o$ nitrophenol, $m$-nitrophenol and $p$-tertiary butyl phenol. J Bioanal Biomed 7: 156-163.

[25] Trivedi MK, Branton A, Trivedi D, Nayak G, Saikia G, Jana S (2015) Characterization of physico-chemical and spectroscopic properties of biofield energy treated 4bromoacetophenone. American Journal of Physical Chemistry 4: $30-37$.

[26] Trivedi MK, Branton A, Trivedi D, Nayak G, Saikia G, Jana S (2015) Chromatographic, spectroscopic, and thermal characterization of biofield energy treated $\mathrm{N}, \mathrm{N}-$ dimethylformamide. American Journal of Applied Chemistry 3: $188-193$

[27] Trivedi MK, Branton A, Trivedi D, Nayak G, Bairwa, K, Jana S (2015) Physicochemical and spectroscopic characteristics of biofield treated $p$-chlorobenzophenone. American Journal of Physical Chemistry 4: 48-57.

[28] Jana S, Trivedi MK, Branton A, Trivedi D, Nayak G, Saikia G. (2015) Physical and structural characterization of biofield energy treated carbazole. Pharm Anal Acta 6: 435.

[29] Trivedi MK, Branton A, Trivedi D, Nayak G, Saikia G, Jana S (2015) Physical and structural characterization of biofield treated imidazole derivatives. Nat Prod Chem Res 3: 187.

[30] Trivedi MK, Branton A, Trivedi D, Nayak G, Saikia G, Jana S (2015) Thermal, spectroscopic and chemical characterization of biofield energy treated anisole. Organic Chem Curr Res 4: 152.

[31] Trivedi MK, Branton A, Trivedi D, Nayak G, Bairwa K, Jana $S$ (2015) Investigation of isotopic abundance ratio of biofield treated phenol derivatives using gas chromatography-mass spectrometry. J Chromatograph Separat Techniq S 6: 003.

[32] Trivedi MK, Branton A, Trivedi D, Nayak G, Gangwar M, Jana S (2015) Effect of biofield energy treatment on chlorophyll content, pathological study, and molecular analysis of cashew plant (Anacardium occidentale L.). Journal of Plant Sciences 3: 372-382.

[33] Sances F, Flora E, Patil S, Spence A, Shinde V (2013) Impact of biofield treatment on ginseng and organic blueberry yield. Agrivita, J Agric Sci 35: 22-29.

[34] Trivedi MK, Branton A, Trivedi D, Nayak G, Mondal SC, Jana S (2015) Evaluation of plant growth, yield and yield attributes of biofield energy treated mustard (Brassica juncea) and chick pea (Cicer arietinum) seeds. Agriculture, Forestry and Fisheries. 4: 291-295.

[35] Trivedi MK, Branton A, Trivedi D, Nayak G, Mondal SC, Jana S (2015) Morphological characterization, quality, yield and DNA fingerprinting of biofield energy treated alphonso mango (Mangifera indica L.). Journal of Food and Nutrition Sciences 3: 245-250.

[36] Nayak G, Altekar N (2015) Effect of a biofield treatment on plant growth and adaptation. J Environ Health Sci 1: 1-9.

[37] Trivedi MK, Branton A, Trivedi D, Nayak G, Bairwa K, Jana S (2015) Physical, thermal, and spectroscopic characterization of biofield energy treated murashige and skoog plant cell culture media. Cell Biology 3: 50-57.

[38] Trivedi MK, Patil S, Shettigar H, Bairwa K, Jana S (2015) Effect of biofield treatment on spectral properties of paracetamol and piroxicam. Chem Sci J 6: 98.

[39] Trivedi MK, Branton A, Trivedi D, Shettigar H, Bairwa K, Jana S (2015) Fourier transform infrared and ultravioletvisible spectroscopic characterization of biofield treated salicylic acid and sparfloxacin. Nat Prod Chem Res 3: 186.

[40] Trivedi MK, Patil S, Shettigar H, Singh R, Jana S (2015) An impact of biofield treatment on spectroscopic characterization of pharmaceutical compounds. Mod Chem Appl 3: 159.

[41] Trivedi MK, Patil S, Shettigar H, Mondal SC, Jana S (2015) The potential impact of biofield treatment on human brain tumor cells: A time-lapse video microscopy. J Integr Oncol 4: 141.

[42] Trivedi MK, Patil S, Shettigar H, Gangwar M, Jana S (2015) In vitro evaluation of biofield treatment on cancer biomarkers involved in endometrial and prostate cancer cell lines. J Cancer Sci Ther 7: 253-257.

[43] Weisel CP, Park S, Pyo H, Mohan K, Witz G (2003) Use of stable isotopically labeled benzene to evaluate environmental exposures. J Expo Anal Environ Epidemiol 13: 393-402.

[44] Rosman KJR, Taylor PDP (1998) Isotopic compositions of the elements 1997 (Technical Report). Pure Appl Chem 70: 217235 .

[45] Smith RM (2004) Understanding Mass Spectra: A Basic Approach, Second Edition, John Wiley \& Sons, Inc.

[46] Jürgen H (2004) Gross Mass Spectrometry: A Textbook (2 $2^{\text {nd }}$ Edn) Springer: Berlin.

[47] http://webbook.nist.gov/cgi/cbook.cgi?ID=C88755\&Mask=20 0\#Mass-Spec.

[48] Sparkman DO, Penton Z, Kitson FG (2011) Gas Chromatography and Mass Spectrometry: A Practical Guide $\left(2^{\text {nd }} \mathrm{Edn}\right)$ Elsevier Inc. 
[49] http://webbook.nist.gov/cgi/cbook.cgi?ID=C554847\&Mask=2 00 .

[50] Gordon J (1998) Inside informatics, cambridgesoft.com Article ID: Isotopic Abundance.

[51] Johnstone RAW, Rose ME (1996) Mass Spectrometry for Chemists and Biochemists ( $2^{\text {nd }}$ Edn) Cambridge university press.

[52] http://www.chemguide.co.uk/analysis/masspec/mplus2.html.

[53] http://www.chemguide.co.uk/analysis/masspec/mplus1.html.

[54] http://www.chem.uoa.gr/applets/AppletMS/Appl_Ms2.html.

[55] Wieser ME (2006) Atomic weights of the elements 2005. Pure Appl Chem 78: 2051-2066.

[56] Vanhaecke F, Kyser K (2012) Isotopic composition of the elements In Isotopic Analysis: Fundamentals and applications using ICP-MS ( $1^{\text {st }}$ Edn), Edited by Vanhaecke F, Degryse P. Wiley-VCH GmbH \& Co. KGaA, Weinheim.

[57] Asperger S (2003) Chemical Kinetics and Inorganic Reaction Mechanisms Springer science + Business media, New York.

[58] http://www.eolss.net/sample-chapters/c06/e6-104-01-00.pdf.

[59] Lomas JS, Thorne MP (1982) Structure and isotope effects upon the thermal decomposition of carbamates of highly congested tertiary alcohols. J Chem Soc, Perkin Trans 2 221226.

[60] www.nobelprize.org/nobel_prizes/physics/laureates/2015/adva nced-physicsprize2015. pdf

[61] Balantekin AB (2013) Neutrinos and rare isotopes Journal of Physics: Conference Series 445012022. 